\title{
Induction of dominant transplantation tolerance by an altered peptide ligand of the male antigen Dby
}

\author{
Tse-Ching Chen, Herman Waldmann, and Paul J. Fairchild \\ University of Oxford, Sir William Dunn School of Pathology, Oxford, United Kingdom.
}

\begin{abstract}
$T$ cell reactivity to minor histocompatibility $(\mathrm{mH})$ antigens is responsible for rejection of HLA-matched allografts, limiting the effectiveness of transplantation for the treatment of end-stage organ failure. The deadbox gene Dby is located on the $\mathrm{Y}$ chromosome and encodes an $\mathrm{mH}$ antigen that prompts rejection of male tissues by female mice. Establishing a network of regulatory $T\left(T_{\text {reg }}\right)$ cells that is capable of coercing naive cells to adopt a tolerant phenotype offers an attractive strategy for immune intervention in such deleterious immune responses. While various approaches have successfully induced a dominant form of transplantation tolerance, they share the propensity to provoke chronic, incomplete activation of $\mathrm{T}$ cells. By identifying the $T$ cell receptor (TCR) contact sites of the dominant epitope of the Dby gene product, we have designed an altered peptide ligand (APL) that delivers incomplete signals to naive $\mathrm{T}$ cells from $\mathrm{A} 1 \times \mathrm{RAG}^{-/}$mice that are transgenic for a complementary TCR. Administration of this APL to female transgenic mice polarizes $T$ cells toward a regulatory phenotype, securing a form of dominant tolerance to male skin grafts that is capable of resisting rejection by naive lymphocytes. Our results demonstrate that incomplete signaling through the TCR may establish a network of $T_{\text {reg }}$ cells that may be harnessed in the service of transplantation tolerance.
\end{abstract}

\section{Introduction}

Organ transplantation has revolutionized the management of many disease states by providing an effective treatment for hematopoietic and end-stage organ failure. Although routine typing of donors for HLA compatibility has significantly reduced the burden of alloreactivity, a disparity at multiple minor histocompatibility $(\mathrm{mH})$ loci is frequently sufficient to provoke rejection, requiring longterm immunosuppression for both solid-organ and bone marrow transplantation (1). The induction of dominant transplantation tolerance offers an attractive alternative to regimens involving immunosuppression by setting in place a self-reinforcing network of regulatory $\mathrm{T}\left(\mathrm{T}_{\text {reg }}\right)$ cells. While naturally occurring $\mathrm{T}_{\text {reg }}$ cells, constitutively expressing CD25, nonspecifically suppress many deleterious immune responses (2), potentially aggressive $\mathrm{CD} 4^{+} \mathrm{CD} 25^{-} \mathrm{T}$ cells may also adopt a regulatory phenotype under certain circumstances (3), possibly exerting their regulatory activity in a more antigen-specific manner (4). Although the parameters involved in recruiting naive $\mathrm{T}$ cells to the regulatory pool are poorly defined, situations in which they experience persistent, incomplete signaling seem to unite current protocols aimed at their induction (4). Antigen presentation by immature DCs that are deficient in costimulation has, for example, been shown to polarize responding $\mathrm{T}$ cells toward a regulatory phenotype (5). Likewise, the use of mAb's to

\footnotetext{
Nonstandard abbreviations used: activation-induced cell death (AICD); altered peptide ligand (APL); bone marrow-derived dendritic cell (BMDC); experimental autoimmune encephalomyelitis (EAE); experimental autoimmune myasthenia gravis (EAMG); graft-versus-host disease (GVHD); hen egg lysozyme (HEL); mean fluorescence intensity (MFI); minor histocompatibility $(\mathrm{mH})$; phycoerythrin (PE); recombination-activating gene (RAG); regulatory $\mathrm{T}\left(\mathrm{T}_{\mathrm{reg}}\right)$; $\mathrm{T}$ cell receptor $(\mathrm{TCR})$; thymidine deoxyribose (TdR).

Conflict of interest: The authors have declared that no conflict of interest exists.

Citation for this article: J. Clin. Invest. 113:1754-1762 (2004).

doi:10.1172/JCI200420569.
}

either $\mathrm{CD} 4$ (6) or $\mathrm{CD} 40 \mathrm{~L}$ (7) can induce dominant tolerance by subtly altering the way in which alloreactive $\mathrm{T}$ cells perceive their cognate ligand. Whereas the use of such mAb's may target both aggressive and bystander $\mathrm{T}$ cells, an alternative approach to the delivery of incomplete signals that spares the nonalloreactive repertoire has been suggested by the advent of altered peptide ligands (APLs).

Although for many years the $\mathrm{T}$ cell response to foreign antigen was considered to be all or nothing, subtle changes in the $\mathrm{T}$ cell receptor (TCR) contact residues of dominant epitopes have revealed that a broad spectrum of responses may be elicited from the same population of cells $(8,9)$. While some APLs have been found to act as partial agonists, stimulating a subset of normal activation events (10), others perform the function of competitive antagonists (11) or induce long-term anergy among responding $\mathrm{T}$ cells (12). Furthermore, some APLs have been identified that promote immune deviation, polarizing $\mathrm{T}$ cells away from aggressive Th1 responses toward cells secreting a profile of cytokines with anti-inflammatory properties, suggesting their potential use in vivo for strategies of immune intervention. Accordingly, APLs of well-characterized autoantigenic epitopes have been successfully harnessed for the treatment of adjuvant arthritis in rats (13) as well as experimental autoimmune encephalomyelitis (EAE) (14-17) and experimental autoimmune myasthenia gravis $(\mathrm{EAMG})(18,19)$ in mice.

The growing realization that $\mathrm{mH}$ antigens represent peptide fragments of polymorphic self-proteins presented to $\mathrm{T}$ cells in a conventional MHC-restricted manner $(1,20)$ has raised the prospect of extending such an approach to the treatment of graft-versushost disease (GVHD) and allograft rejection. Indeed, the molecular identification of the human $\mathrm{mH}$ antigen, HA-1, as a diallelic self-protein bearing a single amino acid polymorphism $(21,22)$ has permitted the synthesis of APLs capable of antagonizing the response of polyclonal CTL lines from three patients suffering acute GVHD (23). While the identity of various $\mathrm{mH}$ antigens has 

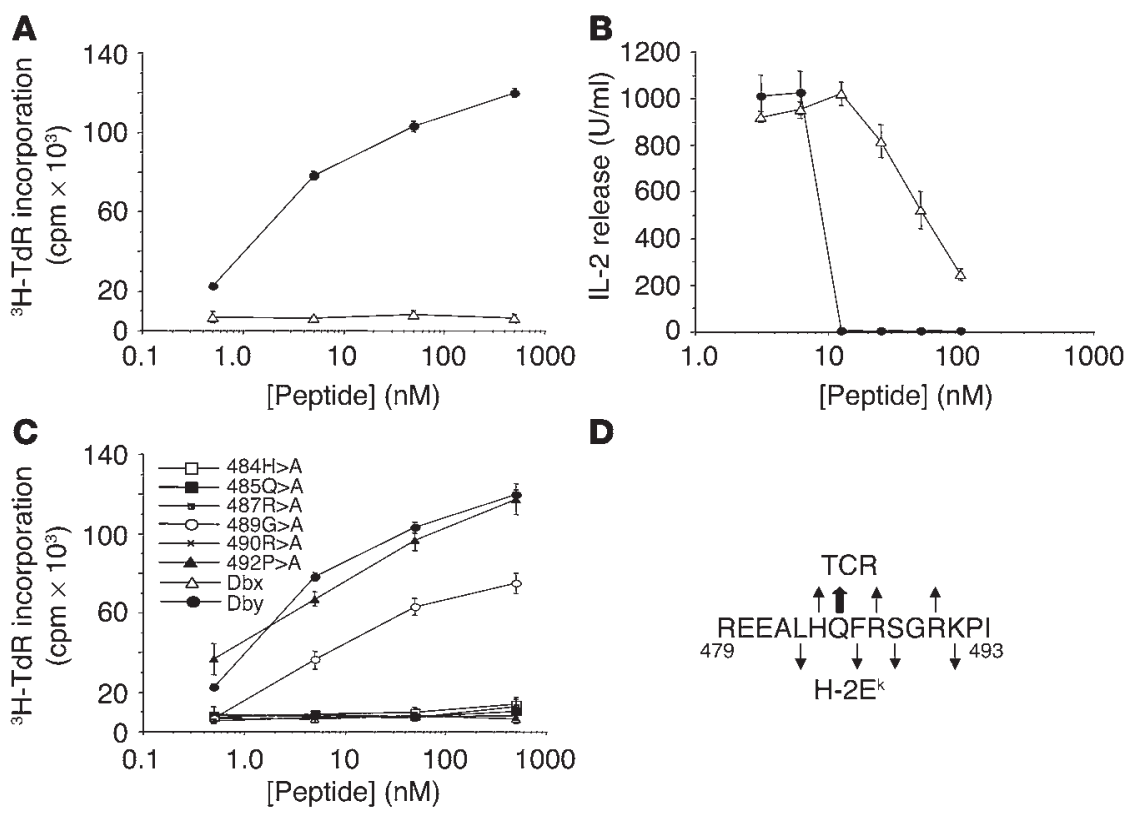

D

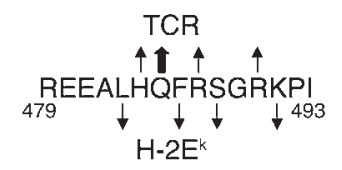

\section{Figure 1}

Identification of the H-2Ek binding motif of the dominant epitope of Dby. (A) Proliferative responses of naive female A1 $\times$ RAG $1^{-1-}$ T cells to the 479-493 peptide from the male antigen, Dby (filled circles), compared with its female homolog, Dbx (open triangles). (B) Competition binding assay showing the enhanced capacity of Dby (filled circles) to compete with $\mathrm{HEL}_{1-18}$ for binding to $\mathrm{H}-2 \mathrm{E}^{\mathrm{k}}$ compared to $\mathrm{Dbx}$ (open triangles), as determined by the extent of inhibition of IL-2 secretion by the 2 G7.1 hybridoma. (C) Stimulatory capacity of analogs of the Dby epitope, substituted with alanine at putative TCR contact residues. (D) Schematic diagram highlighting residues of the Dby epitope that determine its interaction with $\mathrm{H}-2 \mathrm{E}^{\mathrm{k}}$ and the $\mathrm{A} 1$ TCR. The conventional arrows define those residues that interact directly with either the MHC or TCR, while the broad arrow denotes the putative primary TCR contact residue. All data shown are representative of at least three independent experiments.

only recently been elucidated, the nature and importance of malespecific $\mathrm{mH}$ antigens in determining allograft survival has been appreciated since the 1950s. The nonrecombining region of the $\mathrm{Y}$ chromosome in mice contains nine genes whose homologs on the $\mathrm{X}$ chromosome have diverged in sequence, generating a variety of class I- and class II-restricted epitopes (20). Recent elucidation of the dominant epitope of the Dby gene product presented by $\mathrm{H}-2 \mathrm{E}^{\mathrm{k}}$ (24) offers opportunities for the rational design of APLs. Here we show how one such APL, displaying weak agonistic activity, is able to induce transplantation tolerance in mice that are transgenically expressing a complementary TCR by recruiting potentially pathogenic $\mathrm{CD} 4^{+} \mathrm{CD} 25^{-} \mathrm{T}$ cells into a dominant regulatory network.

\section{Results}

Characterization of the dominant $H-2 E^{k}$-restricted epitope of Dby. The Dby gene, located on the $\mathrm{Y}$ chromosome, encodes a deadbox protein that has been shown to act as a source of $\mathrm{mH}$ antigens in the mouse. The immunodominant MHC class II-restricted epitope in mice of the $\mathrm{H}-2^{\mathrm{k}}$ haplotype has recently been determined to lie within residues 479-493 and consists of the following amino acid sequence: REEALHQFRSGRKPI (24). A1 $\times \mathrm{RAG1}^{-/}$mice (RAG, recombination-activating gene) express a transgenic TCR specific for this epitope in the context of $\mathrm{H}-2 \mathrm{E}^{\mathrm{k}}$; while negative selection purges male $\mathrm{A} 1 \times \mathrm{RAG}^{-/-}$mice of immunocompetent $\mathrm{CD}^{+} \mathrm{T}$ cells, thymocytes undergo efficient positive selection in the absence of the cognate ligand, conferring on female mice the capacity to reject grafted tissues from male donors (25). Significantly, the Dby epitope differs from its homolog encoded on the X chromosome at two residues, 490 and 491, represented by K and S, respectively. To dissect the molecular interactions that govern the presentation of this $\mathrm{mH}$ antigen to the A1 TCR, we therefore synthesized the Dby peptide and its Dbx homolog and assessed their capacity to stimulate naive $\mathrm{T}$ cells from female A1 $\times$ RAG1 $1^{-/}$mice. As anticipated, presentation of Dby by female bone marrow-derived dendritic cells (BMDCs) stimulated potent proliferative responses among naive, nylon wool-purified $T$ cells in a dose-dependent fashion. In contrast, the Dbx peptide failed to stimulate at concentrations as high as $500 \mathrm{nM}$ (Figure 1A), suggesting that residues 490 and 491 either contribute to the binding of Dby to $\mathrm{H}-2 \mathrm{E}^{\mathrm{k}}$ or act as critical contact sites for the A1 TCR.

To distinguish between these possibilities, we developed a competition binding assay to determine the relative affinity of the two homologs for their restriction element. The $\mathrm{T}$ cell hybridoma $2 \mathrm{G} 7.1$ is specific for the 1-18 epitope of hen egg lysozyme (HEL $\left.{ }_{1-18}\right)$ in the context of $\mathrm{H}-2 \mathrm{E}^{\mathrm{k}}$ and responds to stimulation by secretion of IL-2. The B cell lymphoma $\mathrm{CH} 27$ was lightly fixed with paraformaldehyde and pulsed with various concentrations of either Dbx or Dby for 1 hour before the addition of $0.5 \mu \mathrm{M} \mathrm{HEL}_{1-18}$ and the $2 \mathrm{G} 7.1$ hybridoma. Figure $1 \mathrm{~B}$ shows the levels of IL-2 detected by ELISA in the culture supernatant 24 hours later. Whereas $100 \mu \mathrm{M}$ Dbx was insufficient to achieve maximal blockade of $\mathrm{H}-2 \mathrm{E}^{\mathrm{k}}$ molecules, the Dby peptide was able to completely inhibit activation of $2 \mathrm{G} 7.1$ at concentrations as low as $12.5 \mu \mathrm{M}$, suggesting that residues 490 and/or 491 contribute essential binding energy to the interaction with $\mathrm{H}-2 \mathrm{E}^{\mathrm{k}}$, conferring on the epitope a 10-fold higher affinity for its restriction element than its female homolog.

Elucidation of the crystal structure of $\mathrm{H}-2 \mathrm{E}^{\mathrm{k}}$ bound to two covalently linked peptides (26) has helped illuminate the binding motif shared by epitopes presented by this MHC determinant. The P4 and P6 pockets, toward the center of the binding cleft, seem broadly permissive: while any hydrophobic residue may be accommodated within $\mathrm{P} 4, \mathrm{Q}, \mathrm{D}$, or $\mathrm{N}$ have each been implicated as $\mathrm{P} 6$ anchor residues in $\mathrm{H}-2 \mathrm{E}^{\mathrm{k}}$-restricted epitopes. In contrast, there are stringent requirements for $\mathrm{L}, \mathrm{I}$, or $\mathrm{V}$ for binding to the $\mathrm{P} 1$ pocket and for the interaction of $\mathrm{K}$ with $\mathrm{P} 9$. Given that one of the two residues identified as critical for biological activity of the Dby epitope is a $\mathrm{K}$ and that its replacement with $\mathrm{S}$ correlates with the significant loss of binding affinity evident for Dbx, we surmised that 491 $\mathrm{K}$ may interact directly with $\mathrm{H}-2 \mathrm{E}^{\mathrm{k}}$, anchoring the epitope at the P9 pocket. In support of this contention, the Dby sequence contains a $\mathrm{L}$ at the anticipated location, eight amino acids $\mathrm{N}$-terminal to $491 \mathrm{~K}$, and a hydrophobic F residue at position 486, optimal for interaction with the $\mathrm{P} 4$ pocket. Only S at position 488 fails to comply with the expected binding motif, confirming the leniency with which anchor residues are tolerated at this site (26). 

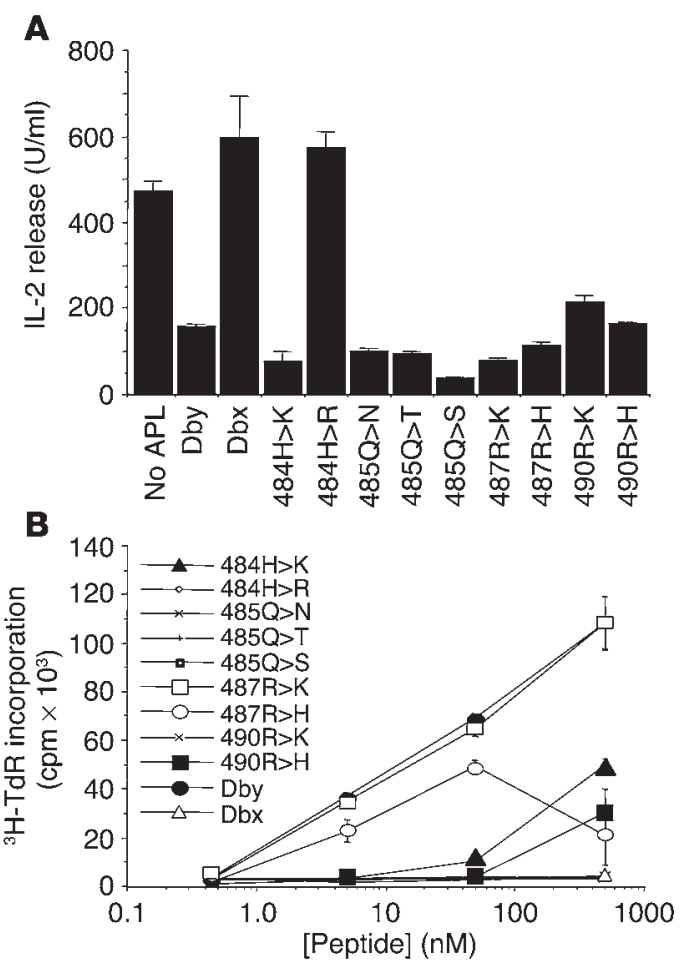

Having deduced the likely binding motif of Dby to comprise the residues $483 \mathrm{~L}, 486 \mathrm{~F}, 488 \mathrm{~S}$, and $491 \mathrm{~K}$, we next investigated which of the intervening amino acid side chains contribute to recognition of the complex by the A1 TCR. A panel of peptide analogs was synthesized bearing $A$ in place of candidate residues, and the response of female A1 $\times \mathrm{RAG}^{-/-} \mathrm{T}$ cells investigated using Dby and Dbx peptides as positive and negative controls. While peptide $492 \mathrm{P} \rightarrow$ A showed no loss of immunogenicity compared to Dby, $489 \mathrm{G} \rightarrow$ A displayed approximately 10 -fold lower activity (Figure $1 \mathrm{C})$, consistent with a secondary effect on neighboring residues. In contrast, substitution of the wild-type residue for $A$ at positions $484,485,487$, and 490 rendered analogs functionally inert, suggesting the corresponding side chains to interact directly with the A1 TCR. Taken together, these results strongly suggest that Dby interacts with its ligands as depicted schematically in Figure 1D.

Design and characterization of APLs. Having defined the molecular interactions that govern the recognition of the Dby epitope, we next constructed a panel of APLs in which putative TCR contact sites were substituted with amino acids displaying similar physicochemical properties to the residue they replaced. Such conservative substitutions have been found to be critical for the design of APLs of class II-restricted epitopes, more fundamental changes most commonly

\section{Figure 3}

The 490R $\rightarrow$ H APL delivers partial activation signals to naive female A1 $\times$ RAG1 ${ }^{-1-}$ T cells. (A) The A1 TCR is rapidly downregulated in response to its cognate ligand, Dby (filled circles), and the agonist peptide 487R $\rightarrow \mathrm{K}$ (open squares). In contrast, neither the female homolog, Dbx (open triangles), nor the partial agonist $490 \mathrm{R} \rightarrow \mathrm{H}$ (filled squares) have any detectable impact on levels of expression of the TCR. (B) Release of IL-10 by naive female $\mathrm{A} 1 \times \mathrm{RAG} 1^{-/} \mathrm{T}$ cells in response to Dby (white bars) or the 490R $\rightarrow$ H APL (black bars). Asterisks denote samples in which IL-10 could not be detected. The results presented are representative of at least three independent experiments.

\section{Figure 2}

Characterization of APLs bearing substitutions at critical TCR contact residues. (A) IL-2 release by $2 \mathrm{G} 7.1$ cultured in the presence of 0.5 $\mu \mathrm{M} \mathrm{HEL}_{1-18}$ and a $100 \mu \mathrm{M}$ excess of APLs. All APLs competed as efficiently as the cognate peptide for binding to $\mathrm{H}-2 \mathrm{E}^{\mathrm{k}}$ with the exception of $484 \mathrm{H} \rightarrow \mathrm{R}$, which bound with similar affinity to the control peptide, Dbx. (B) Proliferative responses of naive female A1 $\times \mathrm{RAG}^{-1-} \mathrm{T}$ cells to APLs bearing conservative substitutions at critical TCR contact sites. All experiments were repeated at least twice and yielded similar results on each occasion.

resulting in a null phenotype (27). Competition binding assays showed most APLs to have an affinity for $\mathrm{H}-2 \mathrm{E}^{\mathrm{k}}$ equal to or greater than that of the cognate Dby peptide (Figure 2A). Only the replacement of $\mathrm{H}$ with $\mathrm{R}$ at position 484 significantly compromised binding affinity, suggesting that this substitution may alter the accessibility of the neighboring anchor residue, $483 \mathrm{~L}$, for the $\mathrm{P} 1$ pocket.

Presentation of APLs to female A1 $\times \mathrm{RAG}^{-/-} \mathrm{T}$ cells resulted in a range of outcomes (Figure $2 \mathrm{~B}$ ). Whereas substitution of residues at positions 484, 487, and 490 yielded either full $(487 \mathrm{R} \rightarrow \mathrm{K})$ or partial agonists $(484 \mathrm{H} \rightarrow \mathrm{K}, 487 \mathrm{R} \rightarrow \mathrm{H}$, and $490 \mathrm{R} \rightarrow \mathrm{H})$ as well as null peptides $(484 \mathrm{H} \rightarrow \mathrm{R}$ and $490 \mathrm{R} \rightarrow \mathrm{K})$, replacement of $485 \mathrm{Q}$ with $\mathrm{N}$, T, or $\mathrm{S}$ resulted in complete loss of stimulatory capacity. That even conservative substitutions were not tolerated at this position strongly suggests that 485 Q serves as the primary TCR contact residue, the remaining residues acting as secondary contact sites (Figure 1D). Since both null peptides and partial agonists may also behave as competitive antagonists of the TCR (11), we next investigated the ability of APLs to inhibit the proliferation of female A1 $\times \mathrm{RAG1}^{-1-}$ T cells cultured with male BMDCs. Although the use of APCs pre-pulsed with the wild-type peptide has been commonly used to distinguish antagonism from MHC blockade $(11,27)$, endogenous expression of the cognate antigen offers the advantage of providing a continuous supply of naturally processed peptides (23). Nevertheless, when using this approach, even supraoptimal concentrations of APLs failed to inhibit $\mathrm{T}$ cell activation by male DCs (data not shown), excluding any antagonistic properties.
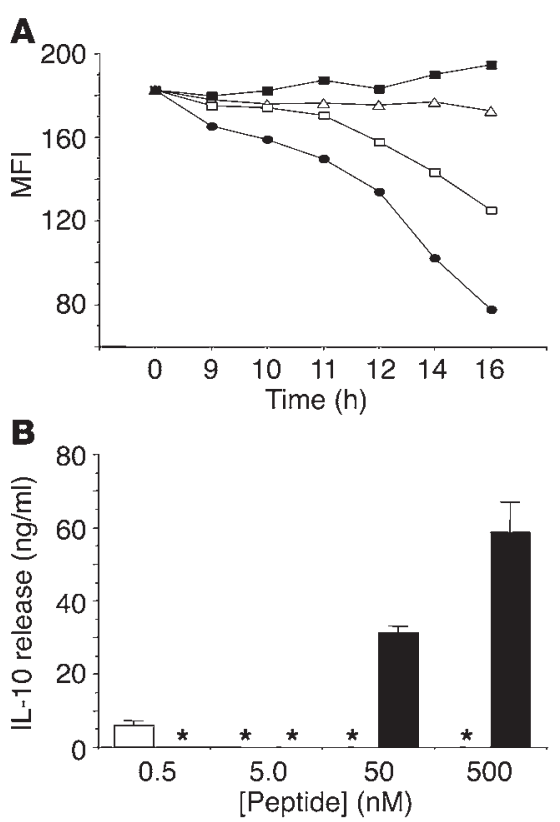


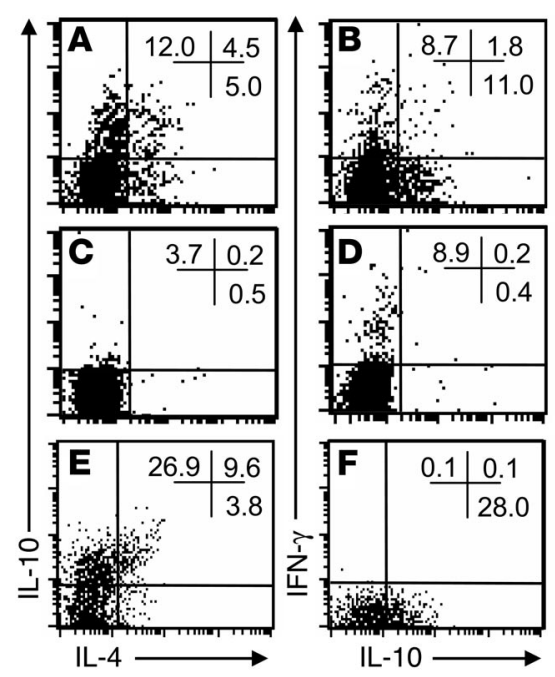

Figure 4

The $490 \mathrm{R} \rightarrow \mathrm{H}$ APL polarizes naive T cells toward a predominantly IL10-secreting phenotype. (A-D) Intracellular cytokine staining of naive A $1 \times$ RAG $^{-/-}$T cells stimulated for 5 days with $500 \mathrm{nM} \mathrm{490R} \rightarrow \mathrm{H}(\mathbf{A}$ and $\mathbf{B})$ or $5 \mathrm{nM}$ Dby (C and $\mathbf{D})$. ( $\mathbf{E}$ and $\mathbf{F})$ Intracellular cytokine staining of $\mathrm{A} 1 \times \mathrm{RAG} 1^{--} \mathrm{T}$ cells stimulated five times at 14-day intervals with the $490 \mathrm{R} \rightarrow \mathrm{H}$ APL to simulate chronic, incomplete stimulation. The results presented are typical of at least three independent experiments.

The 490R $\rightarrow$ H APL polarizes naive T cells toward a regulatory phenotype. To investigate whether the chronic, incomplete activation of naive $\mathrm{CD}^{+} \mathrm{T}$ cells might favor their polarization toward a regulatory phenotype, we selected the APL displaying weakest agonistic activity. That the $490 \mathrm{R} \rightarrow \mathrm{H}$ APL is incapable of delivering full activation signals to Dby-specific T cells was demonstrated by investigating its capacity to stimulate downregulation of the A1 TCR (28). Naive A1 $\times \mathrm{RAG}^{-/}$- T cells were cultured with female BMDCs in the presence of $500 \mathrm{nM}$ peptide, and surface expression of the TCR was assessed at 1-hour intervals by flow cytometry, $\mathrm{CD} 4^{+} \mathrm{T}$ cells being electronically gated so as to exclude contaminating DCs from the analysis. Figure $3 \mathrm{~A}$ shows that the cognate Dby peptide induced rapid downregulation of the TCR that persisted for more than 26 hours (data not shown), whereas its Dbx homolog failed to induce

\section{Figure 5}

The 490R $\rightarrow$ H APL induces dominant transplantation tolerance in vivo. (A) Long-term acceptance of syngeneic male skin grafts by female A1 $\times \mathrm{RAG}^{-/-}$mice treated with five doses of $20 \mu \mathrm{g}$ of $490 \mathrm{R} \rightarrow \mathrm{H}(n=16)$ (filled squares). All control mice receiving the cognate Dby peptide rejected their grafts with a mean survival time of 12 days $(n=7)$ (filled inverted triangle), as did 10/14 mice treated with PBS alone (filled triangles). The results presented are pooled from three independent experiments. (B) Mice rendered tolerant by administration of $490 \mathrm{R} \rightarrow \mathrm{H}(n=5)$ fail to reject existing and fresh skin grafts from male donors when infused with $10^{7} \mathrm{~T}$ cells from naive $\mathrm{A} 1 \times \mathrm{RAG}^{-/-}$mice (filled triangle). The same number of T cells administered to control RAG $1^{-/}$mice $(n=5)$ rapidly mediated graft rejection (filled squares). (C) Neutralization of IL-10 activity fails to abrogate tolerance induced by $490 \mathrm{R} \rightarrow \mathrm{H}$. Mice tolerant of male skin grafts were treated with 1B1.2, specific for the IL-10R $(n=10)$ (filled triangle) or an isotype-controlled $\mathrm{mAb}(n=10)$ (filled inverted triangle) before being infused with $5 \times 10^{6}$ naive $\mathrm{A} 1 \times \mathrm{RAG}^{-/-}$splenocytes and a fresh male skin graft. The same number of naive splenocytes induced rapid rejection of male skin grafts when infused into control RAG1-/recipients $(n=5)$ (filled squares). its internalization, as expected. The $487 \mathrm{R} \rightarrow \mathrm{K}$ APL, which stimulates maximal proliferation of naive $\mathrm{A} 1 \times \mathrm{RAG}^{-/-} \mathrm{T}$ cells (Figure $2 \mathrm{~B}$ ), induced TCR downregulation with kinetics similar to those of the cognate peptide but failed to achieve the same degree of internalization. These results suggest that the threshold of stimulation capable of inducing TCR internalization is greater than that required for proliferation; any disparity between the two readouts may, therefore, indicate the inability of an APL to elicit full T cell activation. Significantly, despite eliciting proliferative responses among naive T cells at a $500 \mathrm{nM}$ concentration (Figure 2B), the same dose of the $490 \mathrm{R} \rightarrow \mathrm{H}$ APL had no observable impact on TCR expression throughout the time course of the assay, confirming the incomplete nature of the signals delivered by $490 \mathrm{R} \rightarrow \mathrm{H}$.

Since APLs bearing subtle changes in the secondary TCR contact residues have been shown previously to direct the differentiation of naive $\mathrm{T}$ cells along distinct lineage pathways both in vitro and in vivo $(15,29-31)$, we assessed the impact on $\mathrm{T}$ cell function of the $\mathrm{R}$ to $\mathrm{H}$ substitution at position 490, by investigating the profile of cytokines released. Surprisingly, despite inducing significantly lower levels of proliferation than the cognate Dby peptide (Figure 2B), 490R $\rightarrow \mathrm{H}$ stimulated naive $\mathrm{T}$ cells to secrete copious amounts of IL-10 in a dose-dependent fashion (Figure 3B). In contrast, IL-10 could only be detected in cultures stimulated with the lowest concentration of the cognate ligand $(5 \mathrm{nM})$ but was consistently close to the limit of detection. To exclude DCs as a potential source of IL-10, we performed intracellular cytokine staining of the $\mathrm{CD}^{+} \mathrm{T}$ cells from these cultures. When stimulated for 5 days with $500 \mathrm{nM} 490 \mathrm{R} \rightarrow \mathrm{H}$ (Figure 4, A and B), 11.0-12.0\% of T cells were found to express IL-10 alone. In contrast, $8.7 \%$ stained positively for IFN- $\gamma$, while $4.5 \%$ expressed both IL-4 and IL-10, consistent with their polarization along the Th2 pathway. In comparison, when stimulated with $5 \mathrm{nM}$ Dby, the

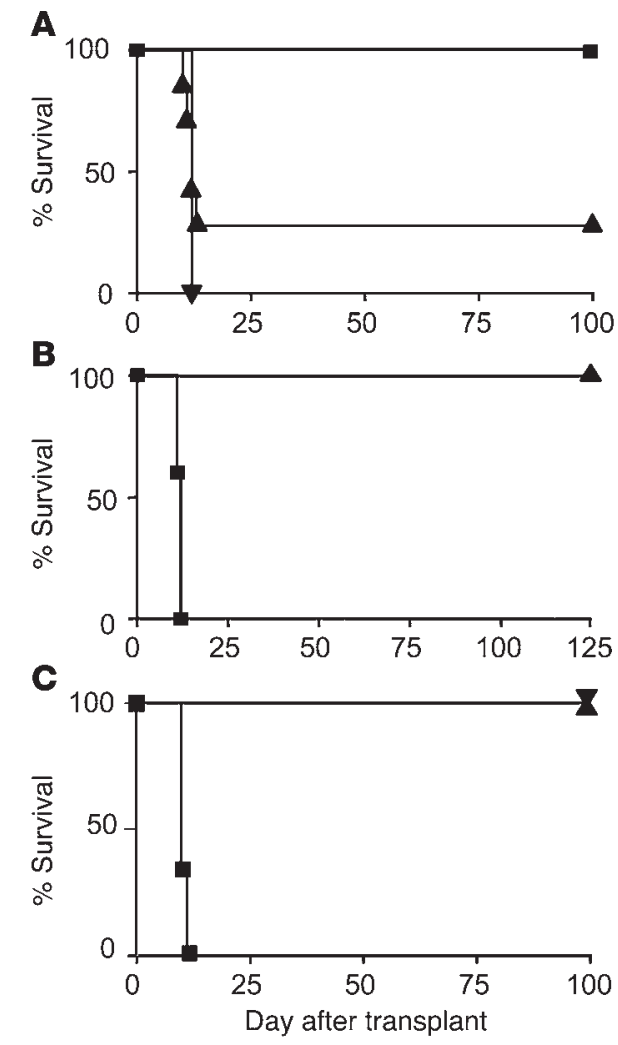




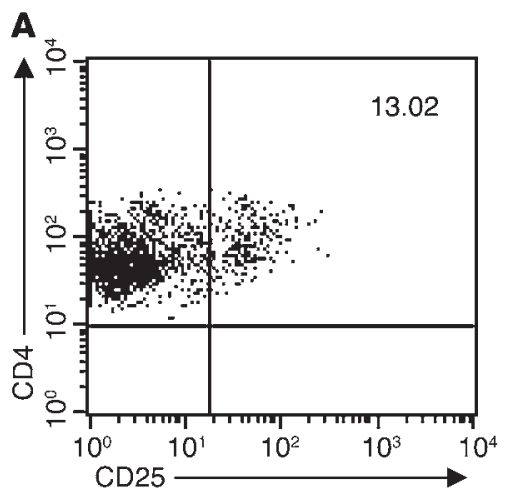

B

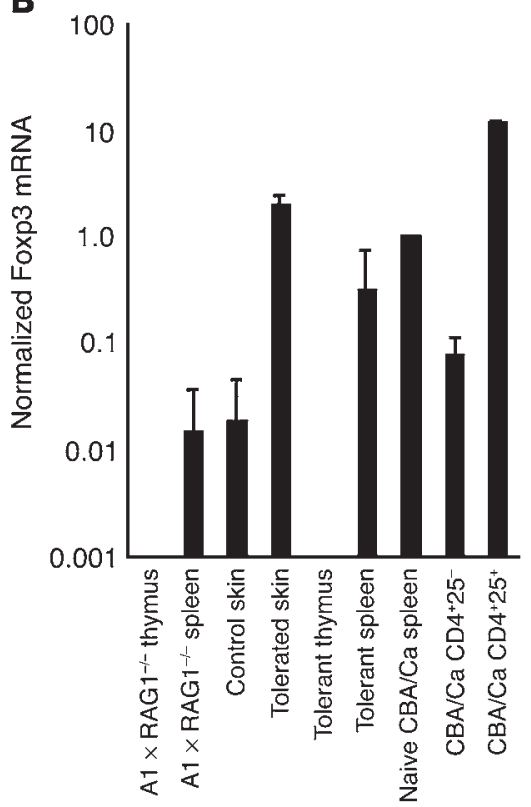

optimal concentration for detection of IL-10 release, only trace numbers of IL-10+ $10^{+}$cells could be detected (Figure 4C), even though $8.9 \%$ had adopted a conventional Th1 phenotype, confirming that priming had occurred (Figure 4D). These results suggest that, even upon initial encounter with the 490R $\rightarrow \mathrm{H}$ APL, A1 $\times \mathrm{RAG}^{-/-} \mathrm{T}$ cells are preferentially polarized toward an IL-10-secreting phenotype.

Predominant secretion of IL-10 has been shown to be a defining feature of $\operatorname{Tr} 1$ cells $(32)$ as well as naturally occurring $(33,34)$ and adaptive $T_{\text {reg }}$ cells (35). To investigate whether chronic, incomplete stimulation of such cells accentuates their polarization toward a $\mathrm{T}_{\text {reg }}$ cell phenotype, we repeatedly stimulated naive $\mathrm{T}$ cells at 14-day intervals with the $490 \mathrm{R} \rightarrow \mathrm{H}$ APL. After five rounds of stimulation, $37.5 \%$ of the cells secreted IL-10, and only a proportion of these also stained positively for IL-4 (Figure 4E). In contrast, cells secreting IFN- $\gamma$ could not be detected (Figure 4F).

The 490R $\rightarrow$ H APL induces dominant transplantation tolerance. Given the propensity of the $490 \mathrm{R} \rightarrow \mathrm{H}$ APL to preferentially polarize responding $T$ cells toward a $T_{\text {reg }}$ cell phenotype, we next investigated whether the same APL could establish dominant transplantation tolerance in vivo. To simulate the chronic, incomplete stimulation of cells we had achieved in vitro, female A1 $\times \mathrm{RAG}^{-/-}$mice were treated i.v. with five doses of $20 \mu \mathrm{g}$ of peptide at 4-day intervals, followed by the application of a skin graft from a syngeneic male RAG1 ${ }^{-/}$donor. Figure 5 A shows that $100 \%$ of mice treated with

\section{Figure 6}

Phenotypic analysis of T cells from mice rendered tolerant of male skin grafts after administration of $490 \mathrm{R} \rightarrow \mathrm{H}$. (A) Flow-cytometric analysis of $T$ cells pooled from six tolerated male grafts confirming the accumulation of $\mathrm{CD} 4{ }^{+} \mathrm{CD} 25^{+}$cells. (B) Real-time quantitative RT-PCR analysis of Foxp3 mRNA expression by tolerated and control skin compared with unfractionated cells from the spleens and thymi of tolerant and naive mice. Populations of $\mathrm{CD} 4{ }^{+} \mathrm{CD} 25^{-}$and $\mathrm{CD} 4{ }^{+} \mathrm{CD} 25^{+} \mathrm{T}$ cells, sorted from naive CBA/Ca mice to greater than $90 \%$ purity, were included as controls. Foxp3 mRNA expression was normalized against CD $3 \gamma$ mRNA levels, so as to correct for the T cell content of each tissue.

the cognate Dby peptide $(n=7)$ rejected the graft promptly with a mean survival time of 12 days. Likewise, 10/14 control mice treated with PBS alone rejected their grafts with the same tempo as recipients of the Dby peptide. In sharp contrast, $100 \%$ of mice pretreated with $490 \mathrm{R} \rightarrow \mathrm{H}(n=16)$ accepted their grafts indefinitely, although before becoming fully established, each underwent a transient rejection crisis, involving partial resorption of the graft and the appearance of hemorrhagic foci. This crisis was almost completely abolished upon administration of $100 \mu \mathrm{g}$ of the APL, suggesting that, with higher doses, a sufficient proportion of T cells may become polarized toward a $\mathrm{T}_{\text {reg }}$ cell phenotype to hold in check any residual aggression, lower doses failing to achieve such a favorable ratio. Nevertheless, despite the initial rejection crisis, all mice treated with 20 $\mu \mathrm{g}$ of $490 \mathrm{R} \rightarrow \mathrm{H}$ ultimately accepted male skin grafts. Furthermore, second skin grafts, applied 60 days later, long after the clearance of peptide from the circulation, were accepted without undergoing the same crisis, confirming that transplantation tolerance had been established. Any involvement of the graft itself in achieving operational tolerance (36) was excluded by omitting the primary skin graft: 12/14 mice, conditioned with the APL 30 days earlier, were still able to accept a male skin graft, despite being denied a source of Dby antigen during this period (data not shown).

To investigate whether $490 \mathrm{R} \rightarrow \mathrm{H}$ had established a dominant regulatory network, we next infused mice that had accepted male skin grafts with $10^{7} \mathrm{~T}$ cells from female $\mathrm{A} 1 \times \mathrm{RAG} 1^{-/-}$mice. Figure $5 \mathrm{~B}$ shows that $5 / 5$ mice conditioned with $490 \mathrm{R} \rightarrow \mathrm{H}$ held both their existing and fresh skin grafts indefinitely, whereas $5 / 5$ control

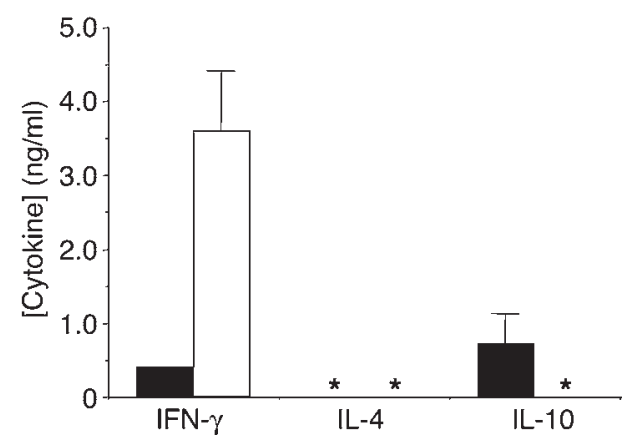

\section{Figure 7}

Female $\mathrm{A} 1 \times \mathrm{RAG}^{-/-} \mathrm{T}$ cells rendered tolerant in vivo by repeated administration of $490 \mathrm{R} \rightarrow \mathrm{H}$ secrete predominantly IL-10 when challenged in vitro with Dby. Cytokine release, measured by ELISA, was determined for $\mathrm{T}$ cells purified from naive (white bars) or tolerant mice (black bars) stimulated ex vivo with $100 \mathrm{nM}$ Dby. Asterisks denote samples in which cytokines could not be detected. Results are representative of four independent experiments. 


\section{Table 1}

Comparison of numbers of CD4+CD8- $T$ cells in the spleen and thymus of tolerant $\mathrm{A} 1 \times \mathrm{RAG}^{-/-}$mice and naive agematched controls

\begin{tabular}{lrr} 
& $\begin{array}{c}\text { Tolerant mice } \\
(\boldsymbol{n}=7)\end{array}$ & $\begin{array}{c}\text { Naive mice } \\
(\boldsymbol{n}=\mathbf{1 1})\end{array}$ \\
& & \\
Spleen & $2.37 \pm 0.89$ & $2.89 \pm 0.76$ \\
Total splenocytes $\left(\times 10^{7}\right)$ & $12.61 \pm 4.51$ & $24.84 \pm 8.03$ \\
$\%$ of CD4 ${ }^{+}$T cells & $2.73 \pm 0.96$ & $7.14 \pm 2.87$ \\
Absolute CD4 ${ }^{+}$T cells $\left(\times 10^{6}\right)$ & & \\
Thymus & $8.12 \pm 1.33$ & $9.26 \pm 3.47$ \\
Total thymocytes $\left(\times 10^{7}\right)$ & $25.92 \pm 3.17$ & $20.7 \pm 6.37$ \\
\% of CD4+CD8 ${ }^{-}$thymocytes & $2.11 \pm 0.48$ & $1.75 \pm 0.19$ \\
Absolute CD4+CD8 ${ }^{-}$thymocytes $\left(\times 10^{7}\right)$ & & \\
\hline & & \\
\hline
\end{tabular}

RAG1 ${ }^{-/}$mice, receiving the same number of naive $\mathrm{T}$ cells, promptly rejected male skin. These results are consistent with the emergence of $\mathrm{T}_{\text {reg }}$ cells in vivo upon persistent exposure to the $490 \mathrm{R} \rightarrow \mathrm{H}$ APL.

To assess the extent to which IL-10 contributes to maintenance of the tolerant state, we made use of 1B1.2, a rat IgG1 mAb specific for the IL-10R, which has been shown previously to potently inhibit IL-10 activity both in vitro (37) and in vivo (33). Female RAG1/- mice were infused with $5 \times 10^{6}$ splenocytes from naive mice or animals rendered tolerant of Dby by treatment with the $490 \mathrm{R} \rightarrow \mathrm{H}$ APL. While control mice receiving naive splenocytes rapidly rejected male skin with a mean survival time of 10 days $(n=5)$ (Figure 5C), mice treated with tolerant cells failed to reject male skin and remained tolerant when subsequently challenged with $5 \times 10^{6}$ naive splenocytes and a second skin graft. Significantly, intraperitoneal administration of 1 $\mathrm{mg}$ of the $1 \mathrm{~B} 1.2 \mathrm{mAb}$ or an isotype control 1 day before grafting and every other day thereafter failed to precipitate graft rejection $(n=10)$ (Figure 5C). The consistent detection by ELISA of high concentrations of rat IgG1 in the serum of these mice strongly suggests that the doses of 1B1.2 used were saturating in vivo (data not shown). These results imply that IL-10 secretion by responding T cells, while consistent with the acquisition of a regulatory phenotype (32), is not essential for the maintenance of tolerance induced by $490 \mathrm{R} \rightarrow \mathrm{H}$.

Recruitment of adaptive $T_{\text {reg }}$ cells and peripheral deletion cooperate to induce the tolerant state. Yamashiro and colleagues reported how the endogenous expression of an APL based on the sequence of a foreign antigenic epitope was able to enhance the selection of naturally occurring $\mathrm{CD} 4^{+} \mathrm{CD} 25^{+} \mathrm{T}_{\text {reg }}$ cells in the thymus of transgenic mice (38). Furthermore, the mode of action of an APL of the acetylcholine receptor in abrogating the onset of EAMG has been attributed to an increase in the number of $\mathrm{CD} 4^{+} \mathrm{CD} 25^{+}$cells in the periphery (19). To further investigate the identity of regulatory cells induced by chronic, incomplete stimulation with $490 \mathrm{R} \rightarrow \mathrm{H}$, we therefore performed flow-cytometric analysis of thymocytes and peripheral $\mathrm{T}$ cells from tolerant and naive $\mathrm{A} 1 \times \mathrm{RAG} 1^{-/-}$mice and enumerated $\mathrm{CD} 4{ }^{+} \mathrm{CD} 25^{+}$cells. Whereas, in the thymus, the number of natural $\mathrm{T}_{\text {reg }}$ cells showed no more than a modest increase from 0.3 to $0.5 \%$ following tolerance induction, peripheral $\mathrm{CD} 4^{+} \mathrm{CD} 25^{+}$ cells increased, on average, from 0.5 to $3.0 \%$. Furthermore, purification and flow-cytometric analysis of $\mathrm{T}$ cells pooled from six tolerated grafts revealed a further enrichment of $\mathrm{CD} 4{ }^{+} \mathrm{CD} 25^{+}$cells that represented, on average, $13.0 \%$ of the total (Figure 6A). Real- time RT-PCR analysis of Foxp3 mRNA within tissues from tolerant and naive mice, normalized to $\mathrm{CD} 3 \gamma$ to correct for $\mathrm{T}$ cell content, showed elevated expression of this forkhead transcription factor (39) in tolerated compared to control skin and in the spleens of tolerant animals compared to naive $\mathrm{A} 1 \times \mathrm{RAG}^{-/-}$mice (Figure $6 \mathrm{~B}$ ). In contrast, the thymi of both tolerant and naive mice failed to express Foxp3, consistent with the absence of natural $\mathrm{T}_{\text {reg }}$ cells in this transgenic strain. These findings suggest that $490 \mathrm{R} \rightarrow \mathrm{H}$ is responsible for directly polarizing naive $\mathrm{T}$ cells toward a $\mathrm{CD} 4{ }^{+} \mathrm{CD} 25^{+}$phenotype with associated upregulation of Foxp3, which does not involve de novo selection of natural $\mathrm{T}_{\text {reg }}$ cells in the thymus.

To investigate whether the $\mathrm{CD} 4^{+} \mathrm{CD} 25^{-}$population also contributed to the tolerant state, $\mathrm{CD} 4^{+} \mathrm{CD} 25^{-} \mathrm{T}$ cells from naive and tolerant mice were sorted to $99.7 \%$ purity and were stimulated in vitro with $100 \mathrm{nM}$ Dby. While naive $\mathrm{CD} 4^{+} \mathrm{CD} 25^{-}$cells released IFN- $\gamma$ alone, their counterparts, isolated from tolerant mice, secreted significantly less of this proinflammatory cytokine, producing, instead, higher titers of IL-10 (Figure 7). This cytokine profile is reminiscent of that produced by naive $\mathrm{A} 1 \times \mathrm{RAG} 1^{-/-} \mathrm{T}$ cells challenged in vitro with $490 \mathrm{R} \rightarrow \mathrm{H}$ (Figure 4 , A and B), suggesting that the $\mathrm{CD} 4^{+} \mathrm{CD} 25^{-}$population in vivo adopts a $\mathrm{Tr} 1$-like phenotype upon exposure to this APL, helping to set the tone of the recipient immune system for dominant tolerance.

Recent studies have highlighted the importance of peripheral deletion as a mandatory prelude to the establishment of dominant transplantation tolerance, the partial depletion of aggressive $T$ cells being required to reduce the burden of alloreactivity, possibly tilting the balance in favor of $\mathrm{T}_{\text {reg }}$ cells $(40,41)$. To determine whether peripheral deletion contributes to the protective effect of $490 \mathrm{R} \rightarrow \mathrm{H}$, we enumerated the absolute numbers of $\mathrm{CD} 4^{+} \mathrm{CD} 8^{-} \mathrm{T}$ cells in the thymi and spleens of naive and tolerant $\mathrm{A} 1 \times \mathrm{RAG}^{-/-}$mice. Table 1 shows that, whereas thymocytes appear refractory to deletion following repeated administration of $490 \mathrm{R} \rightarrow \mathrm{H}$, the absolute number of $\mathrm{CD}^{+}$splenic $\mathrm{T}$ cells decreased significantly from an average of $7.14 \times 10^{6}$ to $2.73 \times 10^{6}$ cells per mouse. These findings strongly suggest that the $490 \mathrm{R} \rightarrow \mathrm{H}$ APL exerts a dual mode of action, reducing the number of aggressive T cells by activation-induced cell death (AICD), while skewing differentiation of the remaining cells toward an adaptive regulatory phenotype, capable of restraining residual alloreactivity.

\section{Discussion}

The first description of APLs, more than a decade ago, marked an important turning point in our understanding of the immune response by uncovering a degree of flexibility in $\mathrm{T}$ cell function that had not previously been anticipated (8). Far from responding to antigen stimulation in a binary fashion, $\mathrm{T}$ cells have since been shown to mount a continuum of responses, the individual components of which may be effectively uncoupled by introducing subtle changes in the TCR contact sites of their cognate ligand (10). The additional demonstration that certain APLs may act as competitive antagonists of the TCR (11) has raised interest in harnessing their properties for immune intervention in a variety of autoimmune and alloimmune settings $(9,23,42)$. Nevertheless, despite early success in rodent models of autoimmune disease (14-19), the problems of antagonizing a polyclonal $\mathrm{T}$ cell repertoire in the face of determinant spreading have yet to be surmounted, greatly complicating the application of such an approach to the clinic (43).

An alternative strategy, which promises to overcome many of these limitations, involves the use of APLs to polarize responding $\mathrm{T}$ cells along defined lineage pathways. Immune deviation 
away from pathogenic Th1 cells using APLs of well-characterized encephalitogenic epitopes, has, for example, proved effective in the treatment of EAE in mice $(14,15)$. Nevertheless, the demonstration that both Th1 and Th2 cells are equally competent to reject foreign tissues (25) highlights the need for a different strategy for the treatment of allograft rejection. Our present findings demonstrate how an APL of the Dby $\mathrm{mH}$ antigen, which fails to act as a competitive antagonist, is able to intervene in the pathogenesis of allograft rejection, setting in place a form of dominant transplantation tolerance. Significantly, administration of the 490R $\rightarrow \mathrm{H}$ APL polarizes naive, antigen-specific $\mathrm{T}$ cells toward a $\mathrm{CD} 4^{+} \mathrm{CD} 25^{-}$ $\operatorname{Tr} 1$-like phenotype, as well as $\mathrm{CD} 4^{+} \mathrm{CD} 25^{+} \mathrm{T}_{\text {reg }}$ cells. These findings suggest that it is feasible not only to skew differentiation of naive $\mathrm{T}$ cells away from a pathogenic Th 1 phenotype but to recruit more than one population of regulatory $T$ cells with a single APL.

In the transgenic mouse model we have studied, $T$ cells exposed to $490 \mathrm{R} \rightarrow \mathrm{H}$ produced little IFN- $\gamma$ or IL-4, secreting predominantly IL-10 both in vitro (Figure $3 \mathrm{~B}$ ) and in vivo (Figure 7), consistent with the reported phenotype of $\operatorname{Tr} 1$ cells (32) and certain populations of $\mathrm{T}_{\text {reg }}$ cells (33-35). Nevertheless, we have shown that persistent blockade of the IL-10R, using the $1 \mathrm{~B} 1.2 \mathrm{mAb}$, fails to compromise the acceptance of male skin grafts (Figure 5C). In contrast to other experimental systems in which a role for IL-10 has been established $(44,45)$, these results therefore suggest that IL-10 release is not essential for maintenance of the tolerant state induced by $\mathrm{T}$ cells polarized through recognition of $490 \mathrm{R} \rightarrow \mathrm{H}$.

Given the dominant nature of tolerance induced with $490 \mathrm{R} \rightarrow$ $\mathrm{H}$, we have explored whether linked suppression might permit the acceptance of additional specificities when presented along with Dby on the same grafted tissue. Such a phenomenon is one of the hallmarks of regulation (46) and is highly desirable in a clinical context, since it might endow a single APL with the capacity to influence responses to multiple $\mathrm{mH}$ antigens. We were, however, unable to unequivocally demonstrate linked suppression in the present case because of nonspecific suppression among control mice, findings that most likely relate to complexities of the TCRtransgenic model. Whereas, under normal circumstances, $\mathrm{T}_{\text {reg }}$ cells may exert their inhibitory effects within the local microenvironment, these microenvironments may prove to be confluent in TCR transgenics in which a critical mass of T cells has become committed to a regulatory phenotype: under such circumstances, responses to "weak" antigens may be nonspecifically suppressed through mechanisms that, in conventional mice, would otherwise manifest as linked suppression. Despite the limitations of our experimental system, there is no reason to believe that the tolerance induced with APLs should be qualitatively different from dominant tolerance established through other experimental interventions. Indeed, the ability of an APL to elicit linked suppression has been elegantly demonstrated in a mouse model of EAE in which administration of an analog based on the dominant epitope of proteolipid protein protected recipients from disease induced by the cognate ligand and by alternative epitopes from the same and unrelated components of the myelin sheath (47).

Irrespective of the difficulties inherent in demonstrating linked suppression, our data help define therapeutic conditions conducive to the development of tolerance and regulation that may prove to be clinically relevant. In particular, they provide further evidence that effective protocols for the induction of dominant tolerance are united by their tendency to provoke persistent, yet incomplete activation of T cells (4), suggested by various lines of investigation. The presentation of antigen by DCs in the absence of inflammatory stimuli has, for example, been shown to promote the differentiation of cells with regulatory properties (48). Furthermore, targeting of antigen under steady-state conditions to immature DCs in situ strongly favors the induction of peripheral tolerance (49). In a therapeutic setting, deprivation of costimulatory signals through blockade of CD40L (7), or antigen encounter under the cover of nondepleting CD4 and CD8 mAb's (6), achieves a similar outcome by attenuating full $T$ cell activation. Our results now extend this paradigm by demonstrating that an APL that has been selected for its capacity to deliver partial activation signals likewise polarizes responding $\mathrm{T}$ cells toward $\mathrm{CD} 4^{+} \mathrm{CD} 25^{-} \mathrm{Tr}$-like cells and $C D 4^{+} C D 25^{+} T_{\text {reg }}$ cells. Although our findings are based on studies of a single $\mathrm{mH}$ antigen, it will be interesting to determine whether other APLs displaying weak stimulatory properties share the capacity to establish a self-sustaining regulatory network. Whereas an essential criterion for the induction of $\mathrm{T}_{\text {reg }}$ cells by an APL may be its partial agonistic properties, our results suggest that its capacity to induce dominant tolerance at the whole-animal level may ultimately be a function of the avidity with which it is recognized. In keeping with other studies $(40,41)$, there appears to be a requirement for avidity to be sufficiently high to secure AICD of a proportion of alloreactive cells (Table 1), so as to establish a favorable ratio between pathogenic and $\mathrm{T}_{\text {reg }} \mathrm{T}$ cells.

Arguably the most important implication of our findings is the light they cast on the immunobiology of $\mathrm{T}_{\text {reg }}$ cells and conditions for their recruitment in vivo. In particular, parameters governing the commitment of $\mathrm{T}$ cells to the adaptive $\mathrm{T}_{\text {reg }}$ cell pathway appear quite distinct from those evident for the selection of naturally occurring $\mathrm{T}_{\text {reg }}$ cells in the thymus. During repertoire selection, it appears to be the recognition of superagonist ligands on thymic cortical epithelium, rather than partial agonists, that is responsible for driving the commitment of thymocytes toward the natural $\mathrm{CD}^{+}{ }^{+} \mathrm{CD} 25^{+}$lineage (50), sharply distinguishing the two subsets $(3,4)$. Interestingly, our inability to detect $\mathrm{CD} 4^{+} \mathrm{CD} 25^{+}$thymocytes in $\mathrm{A} 1 \times \mathrm{RAG}^{-/}$mice, together with the lack of Foxp 3 expression in the thymus (Figure 6), confirms the absence of naturally occurring $\mathrm{T}_{\text {reg }}$ cells in this strain, consistent with findings from other strains of mice on a RAG1/-- background (51). Nevertheless, the finding that Foxp3 mRNA expression is upregulated in tolerated skin grafts where $\mathrm{CD} 4^{+} \mathrm{CD} 25^{+}$cells accumulate argues that a lineage model of regulatory $\mathrm{T}$ cell development based on Foxp3 expression may yet prove overly simplistic.

\section{Methods}

Mice. A1 $\times$ RAG1 ${ }^{-/-}$mice have a CBA/Ca genetic background but constitutively express a TCR (V $\alpha 10$, V $\beta 8.1)$ specific for the 479493 epitope of the Dby gene product in the context of $\mathrm{H}-2 \mathrm{E}^{\mathrm{k}}$ and have been described in detail elsewhere (25). Mice were bred and maintained under specific pathogen-free conditions at the Sir William Dunn School of Pathology, University of Oxford. All experiments were conducted in accordance with the Home Office Animals (Scientific Procedures) Act of 1986 and received local ethical committee approval.

Synthetic peptides. Peptides were synthesized by the MRC Peptide Synthesis Unit, Imperial College School of Medicine, London, United Kingdom, and were assessed for purity by HPLC. All peptides exceeded $95 \%$ purity.

Flow cytometry. All mAb's used for flow cytometry were purchased from BD Biosciences (Cowley, Oxford, United Kingdom). 
Intracytoplasmic staining of cytokines was performed by stimulating naive $\mathrm{A} 1 \times \mathrm{RAG1}^{-/-} \mathrm{T}$ cells or $\mathrm{T}$ cell lines with either cognate peptide or APLs, and T cell-depleted splenocytes or BMDCs as APCs, prepared as described previously (52). Cells were cultured for 4 days ( 5 days for studies of IL-10 release) and supplemented with $10 \mu \mathrm{g} / \mathrm{ml}$ of Brefeldin A (Sigma-Aldrich, Poole, United Kingdom) for the final 4-5 hours. Cells were stained for surface expression of CD4 using FITC-conjugated mAb (clone H129.19; rat IgG2a) and counterstained with $10 \mu \mathrm{g} / \mathrm{ml}$ of 7-Aminoactinomycin D (Sigma-Aldrich) to permit the exclusion of apoptotic cells. After being fixed in $4 \%$ formaldehyde, cells were permeabilized by resuspending them in blocking buffer (PBS $+10 \%$ heat-inactivated normal rabbit serum, $1 \% \mathrm{BSA}$, and $2 \mathrm{mM} \mathrm{NaN}_{3}$ ) containing $0.5 \%$ saponin (Sigma-Aldrich) for 20 minutes on ice. Cells were washed and stained with biotinylated or phycoerythrin-labeled (PE-labeled) mAb's to IFN- $\gamma$ (clone XMG1.2; rat IgG1), IL-4 (clone 11B11; rat IgG1), or IL-10 (clone Jes5-16E3; rat IgG2b) in buffer containing $0.5 \%$ saponin, washed, and fixed in $2 \%$ formaldehyde. For the analysis of surface phenotype, thymocytes and splenic $\mathrm{T}$ cells were stained with mAb's specific for CD4, CD8 (clone 53-6.7; rat IgG2a), and CD25 (clone PC61; rat IgG1), conjugated with FITC, CyChrome (Pharmingen, San Diego, California, USA) and $\mathrm{PE}$, respectively. TCR downmodulation was assessed by culturing naive female $\mathrm{A} 1 \times \mathrm{RAG1}^{-/-} \mathrm{T}$ cells with BMDCs and either the cognate Dby epitope or selected APL. The cells were harvested at varying time points and stained with CD4-CyChrome and biotinylated anti-V $\beta 8.1$ (clone F23.1; mouse IgG2a), which was visualized by means of streptavidin-PE (BD Biosciences). $\mathrm{CD}^{+} \mathrm{T}$ cells were electronically gated and the level of TCR expression determined as a function of mean fluorescence intensity (MFI).

In vitro assays. To determine the relative affinity of APLs for their $\mathrm{H}-2 \mathrm{E}^{\mathrm{k}}$ restriction element, a competition binding assay was developed using, as a readout, IL-2 release by the 2 G7.1 T cell hybridoma (53), specific for $\mathrm{HEL}_{1-18}$ in the context of $\mathrm{H}-2 \mathrm{E}^{\mathrm{k}}$. The B cell lymphoma cell line, $\mathrm{CH} 27$, was lightly fixed in $0.5 \%$ paraformaldehyde, and $5 \times 10^{4}$ cells were added per well of a 96-well flat-bottomed plate. APCs were incubated with a molar excess of APLs $(100 \mu \mathrm{M})$ for 1 hour before being incubated overnight with $5 \times 10^{4} 2 \mathrm{G} 7.1$ and $0.5 \mu \mathrm{M} \mathrm{HEL}_{1-18}$. Supernatants were collected and IL-2 release assessed by means of a standard sandwich ELISA, using Jes6-1A12 (rat IgG2a) as a capture mAb and Jes6-5H4 (rat IgG2b) for the purposes of detection. Supernatant from the X63 cell line, stably transfected with the murine IL-2 gene, was used as a standard to quantify the levels of IL-2 released.

To assess the capacity of APLs to stimulate primary responses, $2 \times 10^{5}$ naive, nylon wool-purified T cells from female A1 $\times$ $\mathrm{RAG}^{-/-}$mice were cultured in triplicate with $5 \times 10^{4}$ mitomycin C-treated BMDCs in 96-well round-bottomed plates with varying concentrations of peptide. Cultures were incubated for a total of 72 hours and were pulsed with $0.5 \mu \mathrm{Ci} /$ well of $\left[{ }^{3} \mathrm{H}\right]$ thymidine (TdR) (Amersham International, Buckinghamshire, United Kingdom) for the final 18-24 hours. Incorporation was measured using a flat-bed scintillation counter (LBK Wallac, Turku, Finland). For an assessment of cytokine release by naive T cells in response to APLs, $50 \mu \mathrm{l}$ of culture supernatant were collected after 48 hours of incubation and the presence of cytokines measured by means of standard sandwich ELISAs using the following pairs of mAb's: for IFN- $\gamma$, clones R46A2 (capture) and XMG1.2 (detection); for IL-4, clones 11B11 (capture) and BVD6-24G2 (rat IgG1) (detection); for IL-10, clones Jes5-
16E3 (capture) and SXC-1 (rat IgM) (detection). Recombinant murine cytokines (R\&D Systems Inc., Minneapolis, Minnesota, USA) were included as positive controls and for the purpose of constructing standard curves.

Tolerance induction and skin grafting. Female A1 $\times$ RAG1/- mice were given five i.v. injections at 4-day intervals of $20 \mu \mathrm{g}$ of either the cognate Dby peptide or the $490 \mathrm{R} \rightarrow \mathrm{H}$ APL in $200 \mu \mathrm{l}$ of PBS. Control mice received PBS alone. Four days after the final injection, fullthickness tail skin $\left(0.5 \mathrm{~cm}^{2}\right)$ from syngeneic RAG1/- male mice was grafted onto a fully vascularized graft bed as described (46).

To assess the role of IL-10 in maintenance of the tolerant state, mice rendered tolerant of male skin grafts were treated intraperitoneally with $1 \mathrm{mg}$ of $1 \mathrm{~B} 1.2 \mathrm{mAb}$ (rat IgG1), specific for the IL-10R, or YCATE55 (an irrelevant isotype control), and were challenged with 5 $\times 10^{6}$ naive $\mathrm{A} 1 \times \mathrm{RAG}^{-/-}$splenocytes the following day, at the same time as a fresh male skin graft. The same dose of 1B1.2 was administered every other day, and saturation was confirmed by monitoring the serum for the presence of rat IgG1 by means of ELISA.

Real-time quantitative RT-PCR. Real-time RT-PCR was used to quantify Foxp3 expression and was performed using an ABI/ PRISM 7700 sequence detector system (Perkin-Elmer Applied Biosystems, Foster City, California, USA). RNA was prepared from mechanically homogenized tissues by means of the SV Total RNA isolation system (Promega Corp., Madison, Wisconsin, USA) which includes DNase I treatment. Reverse transcription was conducted using the proStar kit with random hexamers (Stratagene, La Jolla, California, USA). Multiplex PCR was performed with gene-specific primers, fluorogenic probes, and the Universal MasterMix kit (Perkin-Elmer Applied Biosystems) in triplicate with primers at a concentration of $300 \mathrm{nM}$ and the probe at $200 \mathrm{nM}$. A hot-start, two-step PCR $\left(15\right.$ seconds at $95^{\circ} \mathrm{C}$ and 60 seconds at $60^{\circ} \mathrm{C}$ ) was applied for 40 cycles. Standard curves of appropriate $c D N A s$ were used to calibrate the amounts of cDNA in each test sample. Forward and reverse primer sequences and Taqman probes (Eurogentec, Romsey, Hampshire, United Kingdom). were as follows: Foxp3, forward: 5'-CCCAGGAAAGACAGCAACCTT3', reverse: 5' - TTCTCACAACCAGGCCTCTTG-3'; Taqman: FAM5'-CTACCCACTGCTGGCAAATGGAGTC-3'-TAMRA; CD3 $\gamma$, forward: 5'-TTACAGAATGTGTGAAAACTGCATTG-3', reverse: 5'-CACCAAGAGCAAGGAAGAAGATG-3'; Taqman: VIC-5' ACATAGGCACCATATCCGGCTTTATCTTCG-3'-TAMRA.

\section{Acknowledgments}

We are grateful to Stephen Cobbold for helpful discussions and to Sue Humm for expert technical assistance. This work was funded by a programme grant from the Medical Research Council (United Kingdom). T.-C. Cheng was supported by a studentship from the Chang Gung Memorial Hospital, Taiwan.

Received for publication November 17, 2003, and accepted in revised form March 30, 2004.

Address correspondence to: Paul J. Fairchild, University of Oxford, Sir William Dunn School of Pathology, South Parks Road, Oxford, OX1 3RE, United Kingdom. Phone: 44-1865-275606; Fax: 44-1865275501; E-mail: Paul.Fairchild@path.ox.ac.uk.

Tse-Ching Chen's present address is: Department of Pathology, Chang Gung Memorial Hospital, Chang Gung University School of Medicine, Tao-Yuan, Taiwan. 
1. Goulmy, E. 1997. Human minor histocompatibility antigens: new concepts for marrow transplantation and adoptive immunotherapy. Immunol. Rev. 157:125-140.

2. Sakaguchi, S., et al. 2001. Immunologic tolerance maintained by $\mathrm{CD} 25^{+} \mathrm{CD} 4+$ regulatory T cells: their common role in controlling autoimmunity, tumor immunity, and transplantation tolerance. Immunol. Rev. 182:18-32.

3. Graça, L., et al. 2002. Both $\mathrm{CD}^{+} 25^{+}$and $\mathrm{CD} 4^{+} 25$ regulatory $\mathrm{T}$ cells mediate dominant transplantation tolerance. J. Immunol. 168:5558-5565.

4. Waldmann, H. 2002. Reprogramming the immune system. Immunol. Rev. 185:227-235.

5. Jonuleit, H., Schmitt, E., Schuler, G., Knop, J., and Enk, E.E. 2000. Induction of IL-10-producing, non-proliferating $\mathrm{CD}^{+} \mathrm{T}$ cells with regulatory properties by repetitive stimulation with allogeneic immature human dendritic cells. J. Exp. Med. 192:1213-1222.

6. Qin, S., et al. 1993. 'Infectious' transplantation tolerance. Science. 259:974-977.

7. Honey, K., Cobbold, S.P., and Waldmann, H. 1999. CD40 ligand blockade induces $\mathrm{CD}^{+} \mathrm{T}$ cell tolerance and linked suppression. J. Immunol. 163:4805-4810.

8. Sloan-Lancaster, J., and Allen, P.M. 1996. Altered peptide ligand-induced partial $\mathrm{T}$ cell activation: molecular mechanisms and role in T cell biology. Annu. Rev. Immunol. 14:1-27.

9. Fairchild, P.J. 1997. Altered peptide ligands: prospects for immune intervention in autoimmune disease. Eur. J. Immunogenet. 24:155-167.

10. Evavold, B.D., and Allen, P.M. 1991. Separation of IL-4 production from $T h$ cell proliferation by an altered $\mathrm{T}$ cell receptor ligand. Science. 252:1308-1310.

11. De Magistris, M.T., et al. 1992. Antigen analogmajor histocompatibility complexes act as antagonists of the T cell receptor. Cell 68:625-634.

12. Sloan-Lancaster, J., Evavold, B.D., and Allen, P.M. 1993. Induction of T-cell anergy by altered T-cellreceptor ligand on live antigen presenting cells. Nature. 363:156-159.

13. Wauben, M.H.M., et al. 1992. Disease inhibition by MHC binding peptide analogues of disease-associated epitopes: more than blocking alone. J. Exp. Med. 176:667-677.

14. Karin, N., Mitchell, D.J., Brocke, S., Ling, N., and Steinman, L. 1994. Reversal of EAE by a soluble peptide variant of a myelin basic protein epitope: $T$ cell receptor antagonism and reduction of interferon- $\gamma$ and TNF $\alpha$ production. J. Exp. Med. 180:2227-2237.

15. Nicholson, L.B., Greer, J.M., Sobel, R.A., Lees, M.B., and Kuchroo, V.K. 1995. An altered peptide ligand mediates immune deviation and prevents autoimmune encephalomyelitis. Immunity 3:397-405.

16. Brocke, S., et al. 1996. Treatment of experimental encephalomyelitis with a peptide analogue of myelin basic protein. Nature. 379:343-346.

17. Franco, A., et al. 1994. T cell receptor antagonist peptides are highly effective inhibitors of experimental allergic encephalomyelitis. Eur. J. Immunol. 24:940-946.

18. Katz-Levy, Y., Kirshner, S.L., Sela, M., and Mozes, E. 1993. Inhibition of T cell reactivity to myasthenogenic epitopes of the human acetylcholine receptor by synthetic analogs. Proc. Natl. Acad. Sci. U. S. A. 90:7000-7004.

19. Paas-Rozner, M., Sela, M., and Mozes, E. 2003. A dual altered peptide ligand down-regulates myas- thenogenic $\mathrm{T}$ cell responses by up-regulating CD25- and CTLA-4-expressing CD $4^{+}$T cells. Proc. Natl. Acad. Sci. U. S. A. 100:6676-6681.

20. Simpson, E., and Roopernian, D. 1997. Minor histocompatibility antigens. Curr. Opin. Immunol. 9:655-661.

21. den Haan, J.M.M., et al. 1998. The minor histocompatibility antigen HA-1: A diallelic gene with a single amino acid polymorphism. Science. 279:1054-1057.

22. Mommaas, B., et al. 2002. Identification of a novel HLA-B60-restricted T cell epitope of the minor histocompatibility antigen HA-1 locus. J. Immunol. 169:3131-3136.

23. den Haan, J.M.M., Mutis, T., Blokland, E., Ijzerman, A.P., and Goulmy, E. 2002. General T-cell receptor antagonists to immunomodulate HLA-A2-restricted minor histocompatibility antigen HA-1-specific T-cell responses. Blood 99:985-992.

24. Scott, D., et al. 2000. Dendritic cells permit identification of genes encoding MHC class II-restricted epitopes of transplantation antigens. Immunity. 12:711-720.

25. Zelenika, D., et al. 1998. Rejection of H-Y disparate skin grafts by monospecific $\mathrm{CD} 4^{+} \mathrm{Th} 1$ and Th2 cells: no requirement for $\mathrm{CD} 8^{+} \mathrm{T}$ cells or $\mathrm{B}$ cells. J. Immunol. 161:1868-1874.

26. Fremont, D.H., Hendrickson, W.A., Marrack, P., and Kappler, J. 1996. Structures of an MHC class II molecules with covalently bound peptides. Science. 272:1001-1004.

27. Alexander, J., et al. 1993. Functional consequences of engagement of the TCR by low affinity ligands. J. Immunol. 150:1-7.

28. Valitutti, S., Muller, S., Cella, M., Padovan, E., and Lanzavecchia, A. 1995. Serial triggering of many T-cell receptors by a few peptide-MHC complexes. Nature. 375:148-151.

29. Tao, X., Grant, C., Constant, S., and Bottomly, K. 1997. Induction of IL-4 producing CD4 ${ }^{+} \mathrm{T}$ cells by antigenic peptides altered for TCR binding. J. Immunol. 158:4237-4244.

30. Windhagen, A., et al. 1995. Modulation of cytokine patterns of human autoreactive $T$ cell clones by a single amino acid substitution of their peptide ligand. Immunity. 2:373-380.

31. Pfeiffer, C., et al. 1995. Altered peptide ligands can control CD4 T lymphocyte differentiation in vivo. J. Exp. Med. 181:1569-1574.

32. Groux, H., et al. 1997. A CD4+ T-cell subset inhibits antigen-specific T-cell responses and prevents colitis. Nature. 389:737-742.

33. Asseman, C., Mauze, S., Leach, M.W., Coffman, R.L., and Powrie, F. 1999. An essential role for interleukin-10 in the function of regulatory $\mathrm{T}$ cells that inhibit intestinal inflammation. J. Exp. Med. 190:995-1003.

34. Klein, L., Khazaie, K., and von Boehmer, H. 2003. In vivo dynamics of antigen-specific regulatory $\mathrm{T}$ cells not predicted from behaviour in vitro. Proc. Natl. Acad. Sci. U. S. A. 100:8886-8891.

35. Sundstedt A., O'Neill, E.J., Nicolson, K.S., and Wraith, D.C. 2003. Role for IL-10 in suppression mediated by peptide-induced regulatory $\mathrm{T}$ cells in vivo. J. Immunol. 170:1240-1248.

36. Hamano, K., Rawsthorne, M.A., Bushell, A.R.. Morris, P.J., and Wood, K.J. 1996. Evidence that the continued presence of the organ graft and not peripheral donor microchimerism is essential for maintenance of tolerance to alloantigen in vivo in anti-CD4 treated recipients. Transplantation.
62:856-860.

37. O'Farrel, A-M., Liu, Y., Moore, K.W., and Mui, A.LF. 1998. IL-10 inhibits macrophage activation and proliferation by distinct signaling mechanisms: evidence for Stat3-dependent and-independent pathways. EMBO J. 17:1006-1018.

38. Yamashiro, H., Hozumi, N., and Nakano, N. 2002. Development of CD25+ $\mathrm{T}$ cells secreting TGF- $\beta 1$ by altered peptide ligands expressed as self-antigen. Int. Immunol. 14:857-865.

39. Ramsdell, F. 2003. Foxp 3 and natural regulatory T cells: key to a cell lineage? Immunity. 19:165-168.

40. Wells, A.D., et al. 1999. Requirement for T-cell apoptosis in the induction of peripheral transplantation tolerance. Nat. Med. 5:1303-1307.

41. Zheng X.X., et al. 2003. Favourably tipping the balance between cytopathic and regulatory $\mathrm{T}$ cells to create transplantation tolerance. Immunity. 19:503-514.

42. Daniel, C., Grakoui, A., and Allen, P.M. 1998. Inhibition of an in vitro $\mathrm{CD}^{+} \mathrm{T}$ cell alloresponse using altered peptide ligands. J. Immunol. 160:3244-3250.

43. Bielekova, B. et al. 2000. Encephalitogenic potential of myelin basic protein peptide (amino acid 83-99) in multiple sclerosis: results of a phase II clinical trial with an altered peptide ligand. Nat. Med. 6:1167-1175.

44. Hara, M., et al. 2001. IL-10 is required for regulatory $\mathrm{T}$ cells to mediate tolerance to alloantigens in vivo. J. Immunol. 166:3789-3796.

45. Kingsley, C.I., Karim, M., Bushell, A.R., and Wood, K.J. 2002. CD $25^{+} \mathrm{CD}^{+}{ }^{+}$regulatory $\mathrm{T}$ cells prevent graft rejection: CTLA-4- and IL-10-dependent immunoregulation of alloresponses. J. Immunol. 168:1080-1086.

46. Davies, J.D., Leong, L.Y.W., Mellor, A., Cobbold, S.P., and Waldmann, H. 1996. T cell suppression in transplantation tolerance through linked recognition. J. Immunol. 156:3602-3607.

47. Nicholson, L.B., Murtaza, A., Hafler, B.P., Sette, A., and Kuchroo, V.K. 1997. A TCR antagonist peptide induces $\mathrm{T}$ cells that mediate bystander suppression and prevent autoimmune encephalomyelitis induced with multiple myelin antigens. Proc. Natl. Acad. Sci. U. S. A. 94:9279-9284.

48. Jonuleit, H., Schmitt, E., Schuler, G., Knop, J., and Enk, A.H. 2000. Induction of interleukin 10-producing, nonproliferating $\mathrm{CD}^{+} \mathrm{T}$ cells with regulatory properties by repetitive stimulation with allogeneic immature human dendritic cells. J. Exp. Med. 192:1213-1222.

49. Hawiger, D., et al. 2001. Dendritic cells induce peripheral $\mathrm{T}$ cell unresponsiveness under steady state conditions in vivo. J. Exp. Med. 194:769-779.

50. Jordan, M.S., et al. 2001. Thymic selection of $\mathrm{CD} 4{ }^{+} \mathrm{CD} 25^{+}$regulatory $\mathrm{T}$ cells induced by an agonist self-peptide. Nat. Immunol. 2:301-306.

51. Itoh, M., et al. 1999. Thymus and autoimmunity: production of $\mathrm{CD}_{2} 5^{+} \mathrm{CD} 4+$ naturally anergic and suppressive $T$ cells as a key function of the thymus in maintaining immunologic self-tolerance. J. Immunol. 162:5317-5326

52. Inaba, K., et al. 1992. Generation of large numbers of dendritic cells from mouse bone marrow cultures supplemented with GM-CSF. J. Exp. Med. 176:1693-1702.

53. Adorini, L., et al. 1991. Exogenous peptides compete for the presentation of endogenous antigens to major histocompatibility complex class IIrestricted T cells. J. Exp. Med. 174:945-948. 